Microtus ratticeps (Keys. and Blas.): Newton, ibid. p. 453, f. 1, 2. [Records remains from Crayford and Erith in Mus. Pract. Geol. and F. C. J. Spurrell Coll.]

Myodes lemmus (Linn.) : Newton, Grou. MAG. 1890, p. 455, f. 7, 8. [Recorded from Erith Pleistocene : mandib. ramus and teeth, F. C. J. Spurrell Coll.] torquatus (Desm.) : Newton, ibid. p. 454, f. 3-6. [Recorded from Erith Pleistocene : r. mandib. ramus, F. C. J. Spurrell Coll.]

Neurogymnurus, Filhol. Prof. Rosenberg, of Dorpat, points out that this name, though invariably adopted, is a misprint for Necrogymnurus.

Phoca Moori [n. sp.], E. T. Newton, Quart. Journ. Geol. Soc. vol. xlri. 1890, p. 446, pl. xviii. f. 3. Red Crag: Woodbridge. [L. humerus; E. C. Moor Coll.]

Phocanella minor, P. J. van Beneden: E. T. Newton, Quart. Journ. Geol. Soc. vol xlvi. 1890, p. 447, pl. xviii. f. 4. Red Crag: Woodbridge. [Humerus; E. C. Moor Coll.]

Platycherops Richardsoni, Charlesw. : [R. Lydekker] Ann. Rep. Yorks. Phil. Soc. 1889 (1890), p. 35, pl. 1, f. 1 .

Trogontherium minus [n. sp.], E. T. Newton, Quart. Journ. Geol. Soc. vol. xlvi. 1890 , p. 447 , pl. xvii. f. 5 (? 6).? Includes incisor from Sizenell Gap, Norwich Crag, in Geol. Soc. Mus. (Owen, Brit. Foss. Mamm. 1846, p. 192). Red Crag; Woodbridge. [R. maxilla; E. C. Moor Coll.] ? Norwich Crag; Suffolk.

Xiphodon platyceps, Flower: “May be Dacrytherium ovinum," R. Lydekker, Cat. Foss. Mamm. B.M. pt. ii. 1885, p. 187.

N.B.-General information on the distribution of Pliocene and Pleistocene Fossil Vertebrata will also be found in the following works :-

W. Whitaker, "The Geology of London and of Part of the Thames Valley," 2 vols. 8vo., London (Geol. Survey), 1889.

C. Reid, "The Pliocene Deposits of Britain," 8vo., London (Geol. Survey), 1890. W. and S.

\title{
NOTIOES OF MEITOIRS.
}

\section{I.-Prof. Capeluini on a Fossin Italian Species of Tomistoma.}

G. Capelitini. Sul Cocoonrluiano Garialoide (Tomistoma calaritanus), scoperto nella Collina di Cagliari nel 1868. Mem. Ac. Linc. (4) Vol. VI. 1890, 4 Plates.

TIILL within the last few years the existing Schlegel's Gharial, of Borneo, was the only known representative of the genus Tomistoma, the skull of which is readily distinguished from that of the Gangetic Gharial (Garialis gangeticus) by the forward extension of the nasals to join the premaxillme in the long snout. Within that period fossil remains of this genus have, however, been determined from the Miocene of Malta ( $T$. champsoides) and Lower Austria ( $T$. eggenburgense), while it has been suggested that Blainville's Crocodilus macrorhynchus, from the Cretaceous Pisolite of France, might also be included in the same genus. In the memoir before us the learned Professor of the University of Bologna makes us acquainted with a third species from Italian strata, for which he proposes the name $T$. calaritanus. ${ }^{1}$ This species is described upon the evidence of a skull, somewhat imperfect posteriorly, which was obtained in 1868 from beds at

1 T. calaritanum would appear to be more correct. 
Cagliari, which are probably of Miocene age. Prof. Capellini first gives us a plate illustrating the specimen in the condition in which it was obtained from the quarry, and then a larger plate showing the skull completely extracted from its matrix. All the characteristic features of the genus Tomistoma are displayed in these plates, so that there is no doubt as to the correctness of the generic determination. The general characters are also very similar to those of the Austrian T. eggenburgense (which the author considers is rightly included in Tomistoma, although originally described as Gavialosuchus); but the snout is relatively shorter and thicker, and the supratemporal fossæ are more nearly circular.

The gradually accumulating evidence of the abundance of Tomistoma during the Tertiary period in Europe shows conclusively that the solitary existing species of the genus is one of the many instances of the survival in the Oriental region of ancient European types.

We may mention in passing that the author adopts the amended name Garialis in place of the ordinary and incorrect Gavialis.

\section{R. L.}

II.-Dr. Otto Jakel on Perforating Fungi in Fossil ElasmoBranch TeEth.

"Ginge von Fadenpitzen (Mycelites ossifragus, Roux) in DentinBildungen." By Otto J Jekel. [Sitzungsb. Ges. naturf. Freunde, 1890, pp. 92-91.]

$\mathrm{D}^{\mathrm{C}}$ URING the microscopical examination of sections of the fossil rostral teeth of Pristiophorus, Dr. Jaekel observed the minute branching tubes of a boring organism. The latter he regards as a fungus already described by W. Roux as infesting bones and teeth. Similar borings are recorded in "Sphenodus ornati," Corax heterodon, Acanthias orpiensis, Notidanus primigenius, and a new extinct species of Trygon. We would add that similar borings have already been noticed in fish-scales from the English Chalk.

III.-Dr. W. Dames on a Nothosaurian Reptile from thre Muschelkalk.

"Anarosaurus pumilio, nov. gen., nov. sp." By Prof. W. Dames. [Zeitschr. deutsch. geol. Ges. 1890, pp. 74-85, pl. i.]

? THE author describes the remains of the head, neck, and abdominal 1 region of a small Nothosaurian, from the Lower or Middle Muschelkalk of Remkersleben, west of Magdeburg. The specimen is preserved in the Royal University Museum, Göttingen, and it is well shown with its counterpart, of the natural size, in the plate accompanying the memoir. At first sight the reptile appears to be a miniature Nothosaurus, but it is considered to be generically distinguished by the club-shaped form of its lower side-teeth, and by the total absence of a cleft in the glenoid border of its coracoid. Anarosaurus (as the new genus is termed) is also distinguished from Lariosaurus by its dentition, and differs from the type species of the latter in the slenderness of its ribs and femur, and in the 
relatively greater length of the neck. Pachypleura (or Neusticosaurus) has no front teeth such as characterize the form now described, and there are differences in the limbs. Dactylosau'us is also excluded from comparison both by its short, stout, cervical vertebræ, and by the absence of an epicondylar foramen in the humerus. Dr. Dames' study of the subject leads him to conclude, that all the Triassic Nothosaurus-like reptiles may well be comprised within a single family, that of Nothosauridæ; while the remarkable Mesosauridæ ought not to be regarded as very closely related.

A. S. W.

IV.-ON the Mexican Meteorites, with especial Regard to the supposed occurrence of wide-spread Meteoritic Showers. By L. Fletoner, M.A., F.R.S., with maps of the region. Mineralogical Magazine, Vol. IX. No. 42, pp. 91-180.

TN this most important contribution to Meteoritic Literature, $\mathrm{Mr}$, 1 Fletcher first points ont that the "prevalent belief in widespread meteoritio "showers" is "as regards the desert of Atacama, based on insufficient evidence," and then goes on to make observations, from which it would appear that he includes Mexico in this statement. Mr. Fletcher notes the Meteoritic falls actually observed (only seven in number); the localities in which Meteoritic masses have been found; the distribution in each locality; the transportation of masses; the natural or artificial dispersion of masses belonging to a single type; and the facts which seem to him to prove that many of the masses probably belong to a single fall. Numerous other points are also carefully considered and the history of each known mass is treated in detail, the actual locality being shown on the maps appended. Although dealing with the Meteoritic falls in a limited district, this paper throws a great light on the general subject and will be found most instructive to all those who are interested in cosmical phenomena.

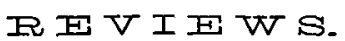

\section{I.-Dr. Ristori on Fossil Italian Apes.}

Ristori, G. Le Scimme Fossili Italiane. Boll. Com. Geol. Vol. VII. Nos. 5-8 (1890).

T $N$ this communication the author affords us some important and interesting information as to the affinities of the fossil Ape from the Miocene of Monte Bamboli known as Oreopithecus bambolii. This Ape was originally described by Gervais on the evidence of an imperfect lower jaw of an immature individual; and was then regarded as being a true anthropoid. Quite recently, however, Dr. Max Schlosser came to the conclusion that the genus has nothing to do with that group, but was very closely allied to Cynocephalus.

Jr. Ristori now describes and figures a number of imperfect jaws, and considers that while there are undoubtedly some signs of affinity with the Cercopithecide, as represented by Semuopithecus and 